\title{
High performance Nd-Fe-B permanent magnets without critical elements
}

\author{
Arjun K. Pathak, ${ }^{1, a}$ K. A. Gschneidner, Jr., ${ }^{1,2}$ M. Khan, ${ }^{1, *}$ R. W. McCallum, ${ }^{1, \#}$ \\ and V. K. Pecharsky ${ }^{1,2}$ \\ ${ }^{1}$ The Ames Laboratory, U.S. Department of Energy, Iowa State University, Ames, Iowa \\ 50011-3020, USA \\ ${ }^{2}$ Department of Materials Science and Engineering, Iowa State University, Ames, Iowa \\ 50011-2300, USA \\ ${ }^{*}$ Current address: Department of Physics, Miami University, Oxford, OH-45056 \\ ${ }^{\#}$ Current address: McCallum Consulting LLC, 1948 Cerros Colorados, \\ Santa Fe NM 87501
}

\begin{abstract}
Scanning electron microscopy, and magnetization measurements reveal that as cast $\left(\mathrm{Nd}_{1-\mathrm{x}} \mathrm{Ce}_{\mathrm{x}}\right)_{2} \mathrm{Fe}_{14} \mathrm{~B}$ alloys contain significant amounts of $\alpha-\mathrm{Fe}$ that can be dramatically reduced by annealing the alloys at $1000{ }^{\circ} \mathrm{C}$ for 3 days. The room temperature intrinsic coercivity, $\mathrm{Hci}$, of $\left(\mathrm{Nd}_{0.8} \mathrm{Ce}_{0.2}\right)_{2.2} \mathrm{Fe}_{14} \mathrm{~B}$ melt spun ribbons was found to be $11 \mathrm{kOe}$, which is $\sim 32$ to $\sim 10 \%$ higher in comparison to that of $\mathrm{Nd}_{2} \mathrm{Fe}_{14} \mathrm{~B}$ ( $\mathrm{Hci}=8.3 \mathrm{kOe}$ ), and $\left(\mathrm{Nd}_{0.8} \mathrm{Ce}_{0.2}\right)_{2.0} \mathrm{Fe}_{14} \mathrm{~B}(\mathrm{Hci}=10 \mathrm{kOe})$, respectively. The substitution of $\mathrm{Co}$ for $\mathrm{Fe}$ in $\left(\mathrm{Nd}_{0.8} \mathrm{Ce}_{0.2}\right)_{2} \mathrm{Fe}_{14-\mathrm{z}} \mathrm{Co}_{\mathrm{Z}} \mathrm{B}$ significantly increases both $\mathrm{T}_{\mathrm{C}}$ and the maximum energy product, (BH)max. Our study shows that both Co-containing and Co-free Ce-substituted $\mathrm{Nd}_{2} \mathrm{Fe}_{14} \mathrm{~B}$ alloys have excellent magnetic properties at room temperature and above. The experimental results also demonstrate the potential of Nd-Ce-Fe-TM-B based alloys as alternative to expensive Dy-containing high performance rare earth magnets.
\end{abstract}

\footnotetext{
a corresponding author: pathak138@ameslab.gov 


\section{Introduction:}

A broad class of existing permanent magnet (PM) materials can be divided into two large groups: i) rare-earth (RE) based PMs such as RE-Fe-B and Sm-Co, and ii) non-RE PMs such as Alnico, ferrites, $\mathrm{Fe}-\mathrm{Ni}$, and $\mathrm{Mn}-\mathrm{Bi}$. Magnets from the second group are generally unsuitable for electric motor applications in vehicles or wind turbines due to insufficient coercivity (Alnico) and/or low magnetization (ferrites) [1]. Therefore, discovery of low cost RE-based PMs or enhancing the performance of RE-free PMs that have large coercivity, Hci, and remanence magnetization, $\mathrm{Br}$, is vitally important. Materials of choice for electric motors are presently based on a variety of Nd-Dy-Fe-B chemistries. Unfortunately, both $\mathrm{Nd}$ and Dy are considered critical elements based on supply risk versus importance to clean energy, [2] thus calling for suitable alternatives to replace Dy and overall reduction of $\mathrm{Nd}$ content in high-performance $\mathrm{Nd}_{2} \mathrm{Fe}_{14} \mathrm{~B}$-based PMs.

Considering natural abundance and cost, $\mathrm{La}$ and $\mathrm{Ce}$ are possible low-cost alternatives to substitute for $\mathrm{Nd}$ in $\mathrm{Nd}_{2} \mathrm{Fe}_{14} \mathrm{~B}$. La is non-magnetic, and hence the substitution of La for $\mathrm{Nd}$ in $\mathrm{Nd}-\mathrm{Fe}-\mathrm{B}$ does not improve the properties required for a strong permanent magnet. However, in some cases La acts as a grain refiner [3]. Ce is another possible candidate where Ce valence may fluctuate between the moment-carrying $\mathrm{Ce}^{+3}$ (for $4 \mathrm{f}^{1}$ configuration) to the non-magnetic $\mathrm{Ce}^{+4}$ (for $4 \mathrm{f}^{0}$ electronic configuration) [4] resulting in a mixed valence state of 3.44 in $\mathrm{Ce}_{2} \mathrm{Fe}_{14} \mathrm{~B}$ [5]. To date, various studies on the development of low-cost Ce-doped RE-Fe-B magnets have been reported [6,7,8,9,10,11]. However, substitution of $\mathrm{Ce}$ for $\mathrm{Nd}$ in $\mathrm{Nd}_{2} \mathrm{Fe}_{14} \mathrm{~B}$ alloy deteriorates the hard magnetic properties due to the low Curie temperature, $\mathrm{Tc}=422 \mathrm{~K}$, low saturation magnetization 
$(4 \pi \mathrm{M}=11.7 \mathrm{kG})$, and low magnetocrystalline anisotropy fields $\mathrm{Ha}(30 \mathrm{kOe})$ of the pure $\mathrm{Ce}_{2} \mathrm{Fe}_{14} \mathrm{~B}$ phase [12].

Recently, we reported that by controlling the microstructure of $\mathrm{Nd}_{2} \mathrm{Fe}_{14} \mathrm{~B}$ with simultaneous substitution of $\mathrm{Nd}$ by $\mathrm{Ce}$, and $\mathrm{Fe}$ by $\mathrm{Co}$ it is possible to develop low cost $\left(\mathrm{Nd}_{0.8} \mathrm{Ce}_{0.2}\right)_{2.4} \mathrm{Fe}_{12} \mathrm{Co}_{2} \mathrm{~B}$ melt spun ribbons that have Hci and $(\mathrm{BH})$ max values of 17.7 kOe, and 12.6 MGOe, respectively [13]. We also observed that critical concentration of Co in $\left(\mathrm{Nd}_{1-\mathrm{x}} \mathrm{Ce}_{\mathrm{x}}\right)_{2} \mathrm{Fe}_{14-\mathrm{y}} \mathrm{Co}_{\mathrm{y}} \mathrm{B}$ depends on the amount of Ce present in the alloy [14]. For example, substitution of one or two Co atoms per formula unit for Fe provides optimum values of Hci and $(\mathrm{BH})$ max in $\left(\mathrm{Nd}_{0.8} \mathrm{Ce}_{0.2}\right)_{2} \mathrm{Fe}_{14-\mathrm{y}} \mathrm{Co}_{\mathrm{y}} \mathrm{B}(\mathrm{y}=1)$ and $\left(\mathrm{Nd}_{0.5} \mathrm{Ce}_{0.5}\right)_{2} \mathrm{Fe}_{14-\mathrm{y}} \mathrm{Co}_{\mathrm{y}} \mathrm{B}(\mathrm{y}=2)$, respectively. Beyond these Co concentrations, the second quadrant of demagnetization curve becomes ill-defined and results in a low (BH)max. The effect of Co on hard magnetic properties for other concentrations of $\mathrm{Ce}$ in $\left(\mathrm{Nd}_{1-\mathrm{x}} \mathrm{Ce}_{\mathrm{x}}\right)_{2} \mathrm{Fe}_{14-\mathrm{y}} \mathrm{Co}_{\mathrm{y}} \mathrm{B}$ remains to be determined. Here, we report the magnetic properties of both bulk polycrystalline, and rapidly solidified nanostructured ribbons of $\mathrm{Ce}$ and $\mathrm{Co}$ co-doped $\left(\mathrm{Nd}_{1-\mathrm{x}} \mathrm{Ce}_{\mathrm{x}}\right)_{2} \mathrm{Fe}_{14-\mathrm{y}} \mathrm{Co}_{\mathrm{y}} \mathrm{B}(0.2 \leq \mathrm{x} \leq 1$, and $0 \leq \mathrm{y} \leq 4)$ compounds. We also studied effect of substitution of Fe by other transition metals such as $\mathrm{Cr}, \mathrm{V}, \mathrm{Mn}, \mathrm{Ni}$ on hard magnetic properties of the $\mathrm{Nd}-\mathrm{Fe}-\mathrm{B}$-based alloys.

\section{Experimental methods:}

The alloys (approximately $15 \mathrm{~g}$ each) were prepared by arc melting followed by drop casting through a $\sim 9.6 \mathrm{~mm}$ diameter orifice at the following compositions: 


$$
\begin{aligned}
& \left(\mathrm{Nd}_{1-\mathrm{x}} \mathrm{Ce}_{\mathrm{x}}\right)_{2+\mathrm{y}} \mathrm{Fe}_{14} \mathrm{~B}(\mathrm{x}=0,0.2 \text {, and } \mathrm{y}=0,0.2) \\
& \left.\left(\mathrm{Nd}_{1-\mathrm{x}} \mathrm{Ce}_{\mathrm{x}}\right)_{2+\mathrm{y}} \mathrm{Fe}_{14-\mathrm{z}} \mathrm{Co}_{\mathrm{z}} \mathrm{B}(0 \leq \mathrm{x} \leq 0.75), \mathrm{y}=0, \text { and } 0 \leq \mathrm{z} \leq 4\right) \\
& \left(\mathrm{Nd}_{1-\mathrm{x}} \mathrm{Ce}_{\mathrm{x}}\right)_{2+\mathrm{y}} \mathrm{Fe}_{14-\mathrm{z}}(\mathrm{Co}, \mathrm{TM})_{\mathrm{z}} \mathrm{B}+2.5 \% \mathrm{ZrC}(\mathrm{x}=0.2, \mathrm{y}=0, \mathrm{TM}=\mathrm{V}, \mathrm{Cr}, \mathrm{Mn}, \mathrm{Ni}),
\end{aligned}
$$

and

$\left(\mathrm{Nd}_{0.8+\mathrm{x}} \mathrm{Ce}_{0.2}\right)_{2+\mathrm{y}} \mathrm{Fe}_{14-\mathrm{z}} \mathrm{Co}_{\mathrm{z}} \mathrm{B}+2.5 \% \mathrm{ZrC}(\mathrm{x}=0.16$, and $\mathrm{y}=0,0.2,0.4$, and $\mathrm{z}=2)$.

The constituent elements, including lanthanides, were of high purity (99.9+ wt.\%) and were obtained from the Materials Preparation Center at the Ames Laboratory. The meltspun ribbons were prepared by induction melting the drop-cast ingots in a quartz crucible under 1/3 atm of high purity He gas and then ejected at 125 torr overpressure onto a copper chill wheel rotating at a tangential speed of $\sim 25 \mathrm{~m} / \mathrm{s}$. The as-spun ribbons were annealed in helium atmosphere at different temperatures. The optimum temperature and time were found to be $600{ }^{\circ} \mathrm{C}$, and 20 minutes, respectively. The magnetization measurements were performed in a Physical Property Measurement System (PPMS) made by Quantum Design Inc. in magnetic field up to $50 \mathrm{kOe}$ and temperatures up to 1000 K. Microstructure, and energy-dispersive x-ray spectroscopy was carried out on a JEOL5910LV scanning electron microscope. The x-ray powder diffraction (XRD) parameters were obtained on a Rigaku TTRAX rotating anode powder diffractometer employing Mo- $K \alpha$ radiation. The phase and lattice parameters were determined from Rietveld analysis using LHPM Rietica [15].

\section{Results and discussion:}

The x-ray diffraction study of as-cast $\left(\mathrm{Nd}_{1-\mathrm{x}} \mathrm{Ce}_{\mathrm{x}}\right)_{2} \mathrm{Fe}_{14} \mathrm{~B}$ showed four different phases: i) major phase 2:14:1; ii) the second most abundant phase $\alpha$-Fe; iii) $\mathrm{CeFe}_{2}$ for $\mathrm{x} \geq 0.25$; and 
iv) 2:17 phase for $x<0.25$. The concentration of the $2: 14: 1$ phase decreases, and the amount of other phases increase with Ce concentration (Table 1). The presence of a significant amount of Fe dendrites in the as-cast samples was also observed in the scanning electron micrographs $(\mathrm{SEM})$ for the $\left(\mathrm{Nd}_{0.8} \mathrm{Ce}_{0.2}\right)_{2} \mathrm{Fe}_{14} \mathrm{~B}$ and $\left(\mathrm{Nd}_{0.8} \mathrm{Ce}_{0.2}\right)_{2.2} \mathrm{Fe}_{14} \mathrm{~B}$ samples (Fig. 1). The energy dispersive spectroscopy analysis shows that the gray/white areas are mainly the 2:14:1 phase, and the black areas are $\alpha$-Fe dendrites (data are not shown). The SEM results along with the magnetization measurements showed that the amount of $\alpha$-Fe decreases with increasing RE concentration beyond 2 atoms per formula unit (not shown). In order to complete solid state reactions and eliminate impurity phases, all bulk samples were heat treated at different temperatures. We found that dropcast alloys annealed at $1000{ }^{\circ} \mathrm{C}$ for 3 days contain more than $97 \%$ of the main $\mathrm{RE}_{2} \mathrm{Fe}_{14} \mathrm{~B}$ phase with less than $2 \%$ of $\alpha$-Fe impurity (Table 1 ), and no $2: 17$, or $\mathrm{CeFe}_{2}$ phases.

The magnetization data as a function of magnetic field for melt spun ribbons at $\mathrm{T}=300 \mathrm{~K}$ of $\left(\mathrm{Nd}_{0.8} \mathrm{Ce}_{0.2}\right)_{2.2} \mathrm{Fe}_{14} \mathrm{~B}$ (Fig. 2) show that adding a small over stoichiometric amount of rare earth significantly increases both the Hci and $(\mathrm{BH}) \max$. The respective values of Hci and (BH)max are $11 \mathrm{kOe}$ and 14.3 MGOe, respectively. These values are higher by $\sim 32$ to $\sim 10 \%$ for Hci and $\sim 4$ to $\sim 30 \%$ for $(\mathrm{BH})$ max when compared to those for $\mathrm{Nd}_{2} \mathrm{Fe}_{14} \mathrm{~B}$ $(\mathrm{Hci}=8.3 \mathrm{kOe},(\mathrm{BH}) \max =13.8 \mathrm{MGOe})$, and $\left(\mathrm{Nd}_{0.8} \mathrm{Ce}_{0.2}\right)_{2.0} \mathrm{Fe}_{14} \mathrm{~B}(\mathrm{Hci}=10 \mathrm{kOe}$, $(\mathrm{BH}) \max =11 \mathrm{MGOe})$, respectively. Figures $2 \mathrm{a}$ and $2 \mathrm{~b}$ show $\mathrm{B}(\mathrm{H})$ loops of $\left(\mathrm{Nd}_{0.8} \mathrm{Ce}_{0.2}\right)_{2.2} \mathrm{Fe}_{14} \mathrm{~B}$ measured at $300 \mathrm{~K}$ and $500 \mathrm{~K}$, respectively. Both loops exhibit "knees" in the $3^{\text {rd }}$ quadrant; this is important for electric motor applications. The Hci and (BH)max for $\left(\mathrm{Nd}_{0.8} \mathrm{Ce}_{0.2}\right)_{2.2} \mathrm{Fe}_{14} \mathrm{~B}$ vary from $11 \mathrm{kOe}$ and $14.3 \mathrm{MGOe}$ at $300 \mathrm{~K}$ to $3.9 \mathrm{kOe}$ 
and 3.2 MGOe at $500 \mathrm{~K}$, respectively (Figs. 2c-d). Considering our previous work [13] on optimization of magnetic properties by adding cobalt and $\mathrm{ZrC}$, we have prepared $\left(\mathrm{Nd}_{0.8} \mathrm{Ce}_{0.2}\right)_{2.2} \mathrm{Fe}_{12} \mathrm{Co}_{2} \mathrm{~B}+2.5 \% \mathrm{ZrC}$ melt spun ribbons. The $\mathrm{Hci}$, and $(\mathrm{BH}) \mathrm{max}$ as a function of magnetic field are shown in Figs. $2 \mathrm{c}$ and 2 d, respectively. Interestingly, the sample with no cobalt and no $\mathrm{ZrC}$ sample has a higher Hci but a lower (BH)max from 300 to $500 \mathrm{~K}$. The slightly better Hci may be attributed to segregation of excess amount of rare earth into the grain boundaries as reported earlier [13]. We have heat treated the melt-spun ribbons at different temperatures and times and found that the heat treatment of the ribbons at $600{ }^{\circ} \mathrm{C}$ for 20 minutes have the optimized magnetic properties for both $\mathrm{Ce}$ and (Ce, Co) co-doped Nd-Fe-B samples (Fig. 3). We believe that the ribbons heat treated at $600{ }^{\circ} \mathrm{C}$ for 20 minutes and bulk samples heat treated at $1000{ }^{\circ} \mathrm{C}$ for 3 days have the optimized microstructure.

We have prepared several $\left(\mathrm{Nd}_{1-\mathrm{x}} \mathrm{Ce}_{\mathrm{x}}\right)_{2} \mathrm{Fe}_{14-\mathrm{z}} \mathrm{Co}_{\mathrm{z}} \mathrm{B}(0 \leq \mathrm{x} \leq 0.75)$, and $\left.0 \leq \mathrm{z} \leq 4\right)$ alloys by arc melting followed by drop-casting, and heat treatment at $1000{ }^{\circ} \mathrm{C}, 3$ days. All Cosubstituted samples exhibited tetragonal $\mathrm{RE}_{2} \mathrm{Fe}_{14} \mathrm{~B}$ phase. The lattice parameters decrease with increasing Co concentration (data not shown), which can be attributed to the smaller radius $(C N=12)$ of $\mathrm{Co}(1.252 \AA)$ compared to Fe $(1.274 \AA)$. The magnetization measurements show that Curie temperatures increase almost linearly with Co for all concentrations of $\mathrm{Ce}$ in $\left(\mathrm{Nd}_{1-\mathrm{x}} \mathrm{Ce}_{\mathrm{x}}\right)_{2} \mathrm{Fe}_{14-\mathrm{z}} \mathrm{Co}_{\mathrm{z}} \mathrm{B}(0 \leq \mathrm{x} \leq 0.75)$, and $\left.0 \leq \mathrm{z} \leq 4\right)$ (Table 2). 
The room temperature magnetization measurements of melt spun ribbons show lower values of $(\mathrm{BH}) \max$ for the samples with $\mathrm{x}=0.25,0.3$ and $\mathrm{z}=0$ in $\left(\mathrm{Nd}_{1-\mathrm{x}} \mathrm{Ce}_{\mathrm{x}}\right)_{2} \mathrm{Fe}_{14-\mathrm{z}} \mathrm{Co}_{\mathrm{z}} \mathrm{B}$ (Fig. 4). These low values are due to the decrease in squareness of hysteresis loop which may be attributed to intergranular magnetically soft phases with Ce substituition [16]. The Curie temperature, $\mathrm{T}_{\mathrm{C}}$, is also decreasing with a Ce concentration. Substitution of Co for Fe increases $T_{C}$. The Co doped samples exhibit not only improved $\mathrm{T}_{\mathrm{C}}$ but they also display enhanced permanent magnetic properties, and thus are promising for various applications. As shown in Fig. 4, Co additions dramatically change the undesirable BH loop behavior to a nearly perfect square magnetic hysteresis loop, while enhancing the $(\mathrm{BH}) \max$. For $\mathrm{x}=0.25,(\mathrm{BH}) \max$ increases from $8.7 \mathrm{MGOe}(\mathrm{z}=0)$ to $13 \mathrm{MGOe}(\mathrm{z}=1$ and 2). For $\mathrm{x}=0.30$, the $(\mathrm{BH})$ max changes from 5.7 MGOe $(\mathrm{z}=0)$ to $14.4 \mathrm{MGOe}(\mathrm{z}=$ 1). The change is more obvious in the demagnetization curves for $x=0.3$ (see Fig. $4 b$ ).

We also investigated the permanent magnetic properties of the melt spun ribbons of several other $\left(\mathrm{Nd}_{1-\mathrm{x}} \mathrm{Ce}_{\mathrm{x}}\right)_{2+\mathrm{y}} \mathrm{Fe}_{14-\mathrm{z}} \mathrm{Co}_{\mathrm{z}} \mathrm{B}$ alloys for $\mathrm{x} \leq 0.5$ and $\mathrm{y}=0$. The obtained values of (BH)max, Br, Hci, and $\mathrm{T}_{\mathrm{C}}$ are summarized in Table 2. The yellow (online, or grey in print) highlighted (listed as bold italic values) rows in Table 2 represent the concentrations with $(\mathrm{BH}) \max >11 \mathrm{MGOe}$. As shown in Table 2, for all Ce concentrations (x), Co doping enhances $(\mathrm{BH}) \max$ and Br. However, Co doping also results in a slight decrease of Hci. In all cases, Co doping enhances the $\mathrm{T}_{\mathrm{C}}$ significantly. Based on the observations presented in Table 2, the $\left(\mathrm{Nd}_{0.8} \mathrm{Ce}_{0.2}\right)_{2} \mathrm{Fe}_{14-\mathrm{z}} \mathrm{Co}_{\mathrm{z}} \mathrm{B}(\mathrm{z}=2)$ alloy appears to be the composition with the most enhanced permanent magnetic properties including a high Curie temperature of $695 \mathrm{~K}$. 
The enhanced (BH)max for certain critical concentrations of Ce and Co is due to a synergistic effect between $\mathrm{Ce}$ and $\mathrm{Co}$ in which the Co atom occupies $\mathrm{Fe}(4 \mathrm{c})$ [17] site, while larger $\mathrm{Ce}^{3+}$ and smaller $\mathrm{Ce}^{4+}$ prefer $\mathrm{RE}(4 \mathrm{~g})$ and $\mathrm{RE}(4 \mathrm{f})$ sites, respectively [18]. Here, the $\mathrm{Fe}(4 \mathrm{c})$ sites are next to the $\mathrm{RE}(4 \mathrm{~g})$ and $\mathrm{RE}(4 \mathrm{f})$ sites and the Co preferentially fills these $\mathrm{Fe}(4 \mathrm{c})$ sites due to its strong affinity for the RE elements. The high coordination of Co surrounding the Ce shifts its valence more toward magnetic $\mathrm{Ce}^{3+}$. Therefore the improved magnetic properties can be attributed to the shift from the nonmagnetic $\mathrm{Ce}^{4+}$ to the magnetic $\mathrm{Ce}^{3+}$.

An almost linear increase of $\mathrm{T}_{\mathrm{C}}$ with increasing Co can be attributed to stronger exchange interactions between Co-Co, or Co-Fe compared to Fe-Fe [19]. The reduction of Hci, and $(\mathrm{BH})$ max beyond the critical concentration of $\mathrm{Co}$ in $\left(\mathrm{Nd}_{0.8} \mathrm{Ce}_{0.2}\right)_{2} \mathrm{Fe}_{14-\mathrm{z}} \mathrm{Co}_{\mathrm{z}} \mathrm{B}$ may be due to the additional Co atoms occupying other Fe sites as suggested by Mössbauer, neutron, and NMR $[20,21,22,23]$ studies of $\mathrm{Nd}_{2} \mathrm{Fe}_{14-\mathrm{z}} \mathrm{Co}_{\mathrm{z}} \mathrm{B}$.

We have also studied the effect of substituting Co with other transition metals. A series of compounds was prepared with various combinations of other transition metals such as $\mathrm{V}, \mathrm{Cr}, \mathrm{Mn}$, and $\mathrm{Ni}$ in the $\left(\mathrm{Nd}_{0.8} \mathrm{Ce}_{0.2}\right)_{2} \mathrm{Fe}_{14-\mathrm{z}}(\mathrm{Co}, \mathrm{TM})_{\mathrm{z}} \mathrm{B}+2.5 \% \mathrm{ZrC}$ alloy where $\mathrm{TM}=\mathrm{V}$, $\mathrm{Cr}, \mathrm{Mn}$, and Ni. Here, we have presented only the relative concentration of $\left(\mathrm{Co}_{1.9} \mathrm{TM}_{0.1}\right)$. Even though we do not have experimental evidence proving that TMs substitute for Co our previous experience with similar compounds (Ref. 14) indicates this as a lively scenario. Magnetization $\mathrm{M}(\mathrm{T})$ measurements show that $\mathrm{T}_{\mathrm{C}}$ decreases with the addition 
TM. For example, substitutions of $\mathrm{Mn}$, or $\mathrm{Cr}$ for Co decrease $\mathrm{T}_{\mathrm{C}}$ by about $40 \mathrm{~K}$ from 695 to $\sim 650 \mathrm{~K}$. Their room temperature magnetic properties: Hci, $(\mathrm{BH}) \mathrm{max}$ Ms and Ha were also measured. The room temperature magnetic hysteresis loops for the melt-spun ribbons of $\left(\mathrm{Nd}_{0.8} \mathrm{Ce}_{0.2}\right)_{2} \mathrm{Fe}_{12}\left(\mathrm{Co}_{1.9} \mathrm{TM}_{0.1}\right) \mathrm{B}+2.5 \% \mathrm{ZrC}, \mathrm{TM}=\mathrm{V}, \mathrm{Cr}, \mathrm{Mn}$, and Ni are shown in Fig. 5, where the intrinsic coercivity (Hci) varies from 8.7 for $\mathrm{Cr}$ to $10.2 \mathrm{kOe}$, for $\mathrm{V}$ doped sample, which compares to Hci $=10.2 \mathrm{kOe}$ for the un-doped sample. Although, the substitution of $\mathrm{Cr}$ and $\mathrm{Mn}$ slightly decreases Hci, the maximum energy product ((BH)max) increases (16.6 MGOe for Mn to 18.7 MGOe for Cr doped) compared to the earlier reported value for the unsubstituted of $\left(\mathrm{Nd}_{0.8} \mathrm{Ce}_{0.2}\right)_{2} \mathrm{Fe}_{12} \mathrm{Co}_{2} \mathrm{~B}+2.5 \% \mathrm{ZrC}$ alloy $((\mathrm{BH}) \max =16.2 \mathrm{MGOe}$, see Table 3$)$. The composition of the $\mathrm{Cr}$ containing sample was further modified to $\left(\mathrm{Nd}_{0.8} \mathrm{Ce}_{0.2}\right)_{2.4} \mathrm{Fe}_{12}\left(\mathrm{Co}_{1.9} \mathrm{Cr}_{0.1}\right) \mathrm{B}+2.5 \% \mathrm{ZrC}$, by adding an extra amount of $\mathrm{Nd}+\mathrm{Ce}$. At $300 \mathrm{~K}$, Hci increased to $16.8 \mathrm{kOe}$ but (BH)max decreased to $9.8 \mathrm{kOe}$ (Table 3). The saturation magnetization varies from 14.9 to $16.9 \mathrm{kG}$ for $\mathrm{TM}=\mathrm{V}$, and $\mathrm{Cr}$, respectively in $\left(\mathrm{Nd}_{0.8} \mathrm{Ce}_{0.2}\right)_{2} \mathrm{Fe}_{12}\left(\mathrm{Co}_{1.9} \mathrm{TM}_{0.1}\right) \mathrm{B}+2.5 \% \mathrm{ZrC}$ alloys. Similarly, the anisotropy field varies from 65 to $68.3 \mathrm{kOe}$ for the respective alloys (Table 3).

We have further optimized the alloy composition by adding $\mathrm{ZrC}$, and excess $\mathrm{Nd}$ and/or Ce in $\left(\mathrm{Nd}_{1-\mathrm{x}} \mathrm{Ce}_{\mathrm{x}}\right)_{2} \mathrm{Fe}_{14-\mathrm{z}} \mathrm{Co}_{\mathrm{z}} \mathrm{B}$. It was shown that the addition of $\mathrm{TiC}$ or $\mathrm{ZrC}$ enhances glass-forming ability [24], reduces grain size, and produces a uniform microstructure [25,26]. The results for $\left(\mathrm{Nd}_{0.8+\mathrm{x}} \mathrm{Ce}_{0.2}\right)_{2+\mathrm{y}} \mathrm{Fe}_{12} \mathrm{Co}_{2} \mathrm{~B}+2.5 \% \mathrm{ZrC}$ are shown in Fig. 6. When excess $\mathrm{Nd}$ and/or $\mathrm{Ce}$ are added, the coercivity can be significantly enhanced while maintaining the large $(\mathrm{BH}) \max , \mathrm{Ms}$ and $\mathrm{T}_{\mathrm{C}}$ values. Fig. 6a shows that addition of excess 
$(\mathrm{Nd}+\mathrm{Ce})$ increases $\mathrm{Hci}$, and it tends to saturate for $\mathrm{x}=0.16$, and $\mathrm{y} \geq 0.2$ in

$\left(\mathrm{Nd}_{0.8+\mathrm{x}} \mathrm{Ce}_{0.2}\right)_{2+\mathrm{y}} \mathrm{Fe}_{12} \mathrm{Co}_{2} \mathrm{~B}+2.5 \% \mathrm{ZrC}$. The temperature dependence of Hci for $\mathrm{x}=0.16, \mathrm{y}$ $=0.4$ varies from $\sim 18.9 \mathrm{kOe}$ at $300 \mathrm{~K}$ to $\sim 5.8 \mathrm{kOe}$ at $500 \mathrm{~K}$. Similarly, $(\mathrm{BH}) \mathrm{max}$ varies from $15 \mathrm{MGOe}$ at $300 \mathrm{~K}$ to $6.8 \mathrm{MGOe}$ at $500 \mathrm{~K}$ for $\mathrm{x}=0.16, \mathrm{y}=0.4$. In addition, the high temperature $(>450 \mathrm{~K}) \mathrm{Hci}$ and $(\mathrm{BH}) \max$ values for $\mathrm{x}=0.16, \mathrm{y}=0.2$, and 0.4 are higher than those of $x=0.16, y=0$. The temperature coefficient of the coercivity $(\beta)$, and the temperature coefficient of $\operatorname{Br}(\alpha)$ are $\sim-0.3 \% \mathrm{~K}^{-1}$ to $-0.1 \% \mathrm{~K}^{-1}$, respectively. The room temperature anisotropy, Ha, and remanence magnetization varies from $62 \mathrm{kOe}$, $8.4 \mathrm{kG}$ for $\mathrm{x}=0, \mathrm{y}=0.4$ to $71.8 \mathrm{kOe}, 8.6 \mathrm{kG}$ for $\left(\mathrm{Nd}_{0.8+\mathrm{x}} \mathrm{Ce}_{0.2}\right)_{2+\mathrm{y}} \mathrm{Fe}_{12} \mathrm{Co}_{2} \mathrm{~B}+2.5 \% \mathrm{ZrC}, \mathrm{x}$ $=0.16, \mathrm{y}=0.4$, respectively .

\section{Conclusion:}

In summary, we have investigated the hard magnetic properties of as cast and heat treated co-doped with $\mathrm{Ce}$ and $\mathrm{Co}\left(\mathrm{Nd}_{1-\mathrm{x}} \mathrm{Ce}_{\mathrm{x}}\right)_{2} \mathrm{Fe}_{14-\mathrm{z}} \mathrm{Co}_{\mathrm{z}} \mathrm{B}$ alloys in bulk polycrystalline and nanocrystalline melt-spun ribbon states. Experimentally we determine the various compositions of isotropic magnets with $\mathrm{T}_{\mathrm{C}}>375^{\circ} \mathrm{C}$ which have $300 \mathrm{~K}$ magnetic properties with Ms > $13 \mathrm{kG}$, Hci between 10 and $19 \mathrm{kOe}$ and $(\mathrm{BH})$ max between 10 and 18 MGOe. The values of the temperature coefficient of the $\operatorname{Br}(\alpha)$, and coercivity $(\beta)$ are $-0.1 \% /{ }^{0} \mathrm{C}$ and $-0.3 \% /{ }^{0} \mathrm{C}$, respectively. These magnetic properties are superior to those of several recently reported Ce-substituted Nd-Fe-B based alloys $[27,28]$. We also observed that in addition to $\mathrm{Co}, \mathrm{Mn}$ and $\mathrm{Cr}$ can be substituted for Fe while retaining good magnetic properties in $\left(\mathrm{Nd}_{0.8} \mathrm{Ce}_{0.2}\right)_{2} \mathrm{Fe}_{12}\left(\mathrm{Co}_{1.9} \mathrm{TM}_{0.1}\right) \mathrm{B}+2.5 \% \mathrm{ZrC}, \mathrm{TM}=\mathrm{V}, \mathrm{Cr}, \mathrm{Mn}$, and Ni. Although Co was once (in 1980's-1990's) considered to be a critical element, today 
there are several sources in few countries located in various parts of the world, so the supply of Co is not critical, but the metal is still relatively expensive. Our study alleviates the criticality of Dy and $\mathrm{Nd}$ by substitution of Ce which is the most abundant and lowest cost rare earth element. The cost of components in the Ce, Co co-doped alloys is significantly lower compared to the $\mathrm{Nd}_{2} \mathrm{Fe}_{14} \mathrm{~B}+2 \%$ Dy alloy which makes the materials described here attractive alternatives for Dy containing Nd-Fe-B magnets.

\section{Acknowledgements}

This work was supported by the U.S. Department of Energy (DOE), Advanced Research Projects Agency-Energy (ARPA-E), Rare Earth Alternatives in Critical Technologies for Energy (REACT). The research was performed at the Ames Laboratory which is operated for the U.S. DOE by Iowa State University under contract \#DE-AC02-

07CH11358. The authors would like to thank Matthew Abben, Matthew Kenney, and Matthew Wheaton for their help preparing melt spun ribbon samples. 


\section{Figure and Table Captions:}

Fig. 1: Backscattered electron SEM images of the as cast $\left(\mathrm{Nd}_{0.8} \mathrm{Ce}_{0.2}\right)_{2.0} \mathrm{Fe}_{14} \mathrm{~B}$ (left), and $\left(\mathrm{Nd}_{0.8} \mathrm{Ce}_{0.2}\right)_{2.2} \mathrm{Fe}_{14} \mathrm{~B}$ (right) samples. The gray/white area is the 2:14:1 phase, and dark black area is the Fe dendrites.

Fig. 2 (color online): Magnetization as function of magnetic field for melt spun ribbons

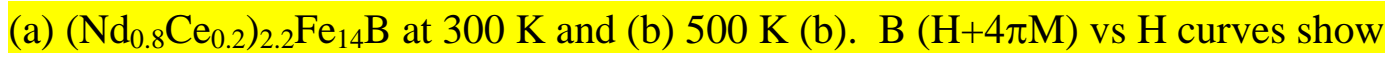
"knees" (dotted circle) in the 3rd quadrant up to $500 \mathrm{~K}\left(227^{\circ} \mathrm{C}\right)$. (c) Intrinsic coercivity, Hci vs. temperature and (d) maximum energy product, $(\mathrm{BH}) \max , v s$. temperature for melt spun ribbons $\left(\mathrm{Nd}_{0.8} \mathrm{Ce}_{0.2}\right)_{2.2} \mathrm{Fe}_{14} \mathrm{~B}$ and $\left(\mathrm{Nd}_{0.8} \mathrm{Ce}_{0.2}\right)_{2.2} \mathrm{Fe}_{12} \mathrm{Co}_{2} \mathrm{~B}+2.5 \% \mathrm{ZrC}$.

Fig. 3 (color online): Magnetization as function of magnetic field for melt spun ribbons (a) $\left(\mathrm{Nd}_{0.75} \mathrm{Ce}_{0.25}\right)_{2} \mathrm{Fe}_{14} \mathrm{~B}$, and (b) $\left(\mathrm{Nd}_{0.8} \mathrm{Ce}_{0.2}\right)_{2} \mathrm{Fe}_{12} \mathrm{Co}_{2} \mathrm{~B}$ heat treated at different temperatures.

Fig. 4 (color online): Magnetization versus magnetic field for melt spun ribbons (a) $\left(\mathrm{Nd}_{0.75} \mathrm{Ce}_{0.25}\right)_{2} \mathrm{Fe}_{14-\mathrm{z}} \mathrm{Co}_{\mathrm{z}} \mathrm{B}$ and (b) $\left(\mathrm{Nd}_{0.7} \mathrm{Ce}_{0.3}\right)_{2} \mathrm{Fe}_{14-\mathrm{z}} \mathrm{Co}_{\mathrm{z}} \mathrm{B}$.

Fig. 5 (color online): Room temperature magnetization versus magnetic field for melt spun ribbons $\left(\mathrm{Nd}_{0.8} \mathrm{Ce}_{0.2}\right)_{2} \mathrm{Fe}_{12}\left(\mathrm{Co}_{1.9} \mathrm{TM}_{0.1}\right) \mathrm{B}+2.5 \% \mathrm{ZrC}, \mathrm{TM}=(\mathrm{a}) \mathrm{V}$, (b) $\mathrm{Cr}$, (c) $\mathrm{Mn}$, and (d) $\mathrm{Ni}$. 
Fig. 6 (color online): (a) Intrinsic coercivity, Hci vs. temperature, and (b) maximum energy product, $(\mathrm{BH}) \max v s$. temperature for melt spun ribbons $\left(\mathrm{Nd}_{0.8+\mathrm{x}} \mathrm{Ce}_{0.2}\right)_{2+\mathrm{y}} \mathrm{Fe}_{12} \mathrm{Co}_{2} \mathrm{~B}+2.5 \% \mathrm{ZrC}$.

\section{Table Captions:}

Table 1: Phase contents of drop cast $\left(\mathrm{Nd}_{1-\mathrm{x}} \mathrm{Ce}_{\mathrm{x}}\right)_{2} \mathrm{Fe}_{14} \mathrm{~B}$ alloys in as-cast (straight font) and heat treated (bold italic) state in wt.\%.

Table 2 (color online): Room temperature values of maximum energy product $(\mathrm{BH}) \mathrm{max}$, remanence magnetization $(\mathrm{Br})$, intrinsic coercivity Hci, Curie temperature $\mathrm{T}_{\mathrm{C}}$ of $\left(\mathrm{Nd}_{1-\mathrm{x}} \mathrm{Ce}_{\mathrm{x}}\right)_{2} \mathrm{Fe}_{14-\mathrm{z}} \mathrm{Co}_{\mathrm{z}} \mathrm{B}$ melt spun ribbons heat treated for 20 minutes at $600{ }^{\circ} \mathrm{C}$. The yellow highlighted (listed as bold italic values) rows represent the concentrations with (BH)max > 11 MGOe.

Table 3: The room temperature magnetic properties: coercivity $\left(\mathrm{H}_{\mathrm{ci}}\right)$, maximum energy product $\left((\mathrm{BH})_{\max }\right)$, saturation magnetization $(\mathrm{Ms})$, and anisotropy field (Ha) of $\left(\mathrm{Nd}_{0.8} \mathrm{Ce}_{0.2}\right)_{2} \mathrm{Fe}_{12}\left(\mathrm{Co}_{1.9} \mathrm{TM}_{0.1}\right) \mathrm{B}+2.5 \% \mathrm{ZrC}, \mathrm{TM}=\mathrm{V}, \mathrm{Cr}, \mathrm{Mn}$, and Ni. For comparison, the corresponding values of the unsubstituted $\left(\mathrm{Nd}_{0.8} \mathrm{Ce}_{0.2}\right)_{2} \mathrm{Fe}_{12} \mathrm{Co}_{2} \mathrm{~B}+2.5 \% \mathrm{ZrC}$ sample are also provided in the bottom row. 
$\left(\mathrm{Nd}_{0.8} \mathrm{Ce}_{0.2}\right)_{2.0} \mathrm{Fe}_{14} \mathrm{~B}$

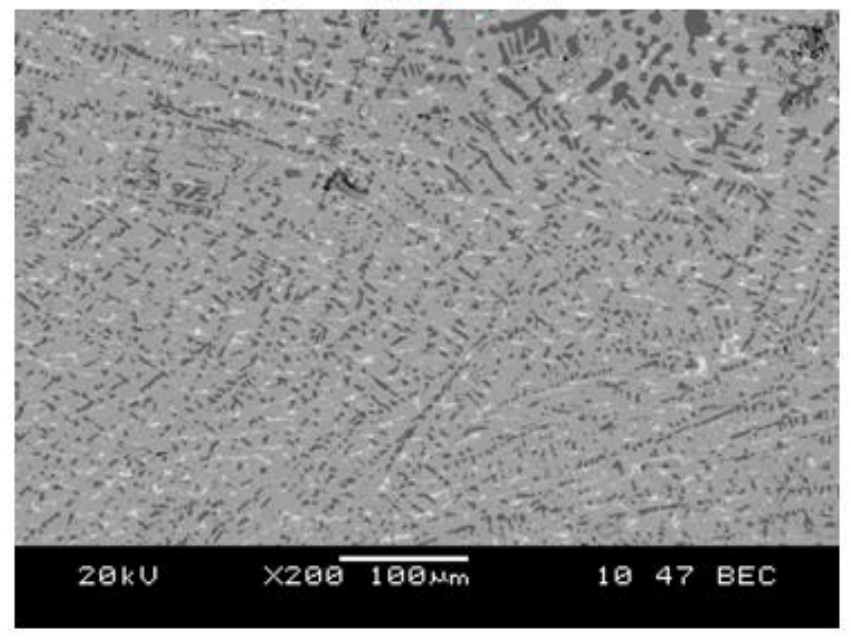

$\left(\mathrm{Nd}_{0.8} \mathrm{Ce}_{0.2}\right)_{2.2} \mathrm{Fe}_{14} \mathrm{~B}$

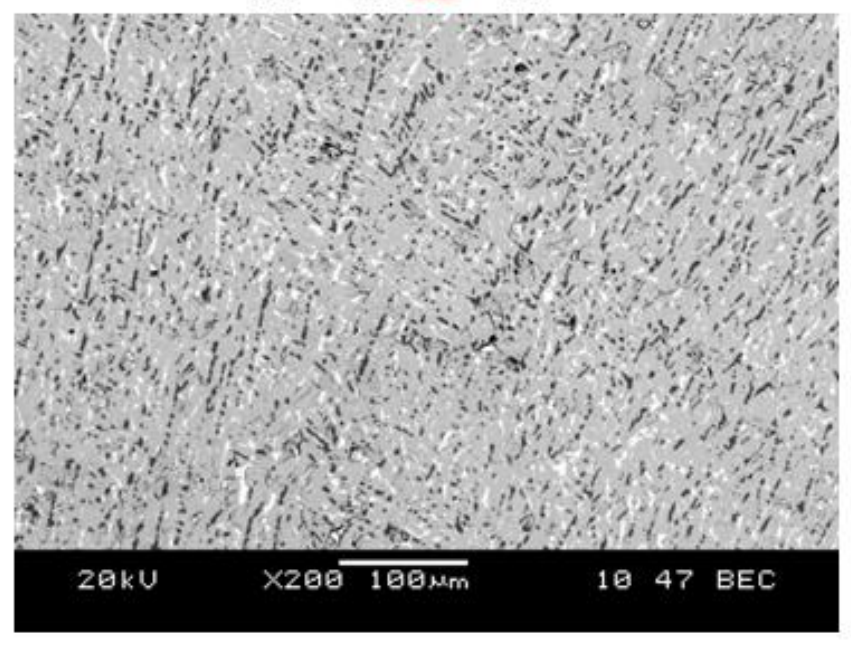

Fig. 1: Backscattered electron SEM images of the as cast $\left(\mathrm{Nd}_{0.8} \mathrm{Ce}_{0.2}\right)_{2.0} \mathrm{Fe}_{14} \mathrm{~B}$ (left), and $\left(\mathrm{Nd}_{0.8} \mathrm{Ce}_{0.2}\right)_{2.2} \mathrm{Fe}_{14} \mathrm{~B}$ (right) samples. The gray/white area is the 2:14:1 phase, and dark black area is the Fe dendrites. 

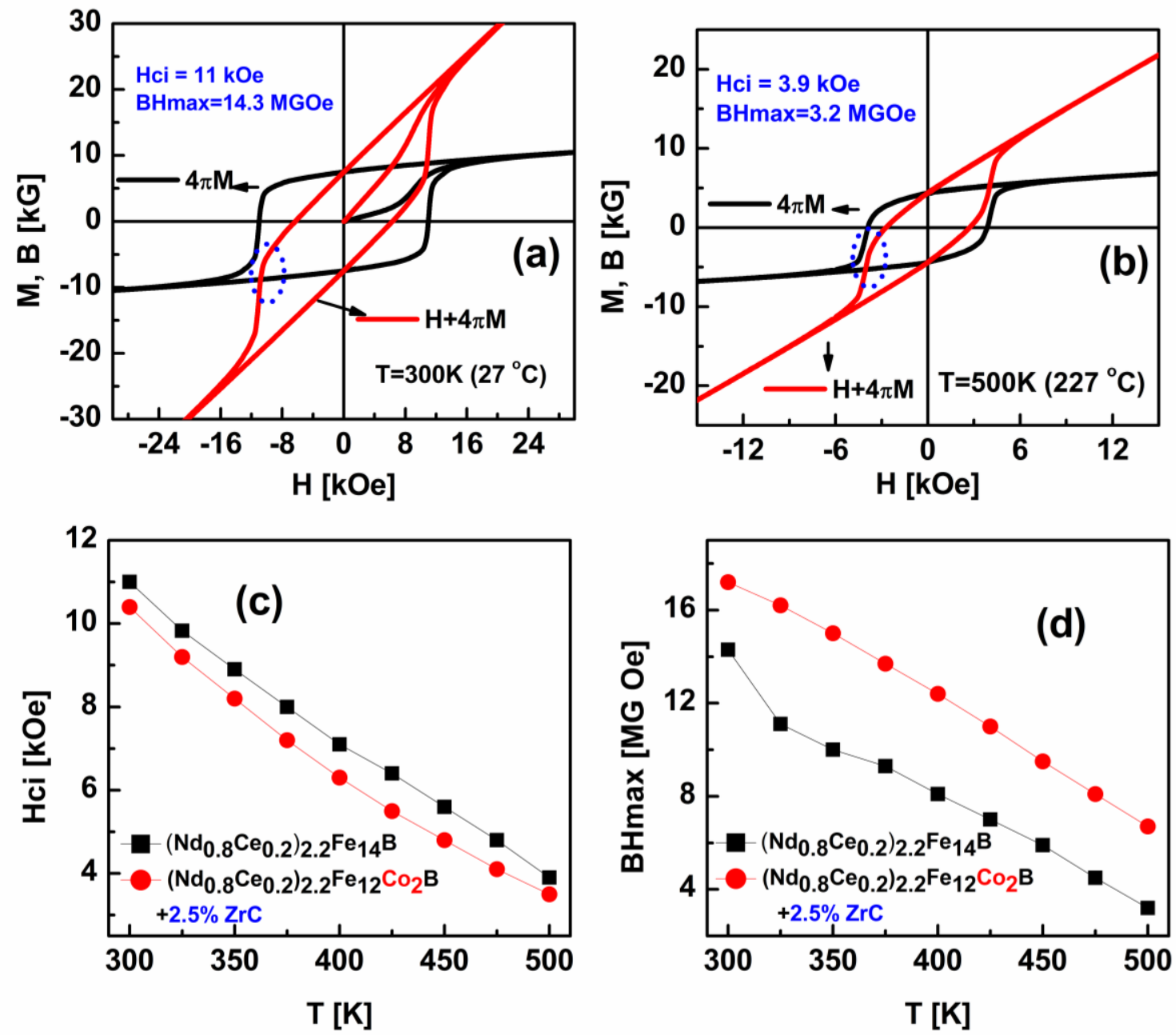

Fig. 2 (color online): Magnetization as function of magnetic field for melt spun ribbons (a) $\left(\mathrm{Nd}_{0.8} \mathrm{Ce}_{0.2}\right)_{2.2} \mathrm{Fe}_{14} \mathrm{~B}$ at $300 \mathrm{~K}$ and (b) $500 \mathrm{~K}$. B $(\mathrm{H}+4 \pi \mathrm{M})$ vs $\mathrm{H}$ curves show "knees" (dotted circle) in the 3 rd quadrant up to $500 \mathrm{~K}\left(227^{\circ} \mathrm{C}\right)$. (c) Intrinsic coercivity, Hci vs. temperature and (d) maximum energy product, $(\mathrm{BH}) \max , v s$. temperature for melt spun ribbons $\left(\mathrm{Nd}_{0.8} \mathrm{Ce}_{0.2}\right)_{2.2} \mathrm{Fe}_{14} \mathrm{~B}$ and $\left(\mathrm{Nd}_{0.8} \mathrm{Ce}_{0.2}\right)_{2.2} \mathrm{Fe}_{12} \mathrm{Co}_{2} \mathrm{~B}+2.5 \% \mathrm{ZrC}$. 

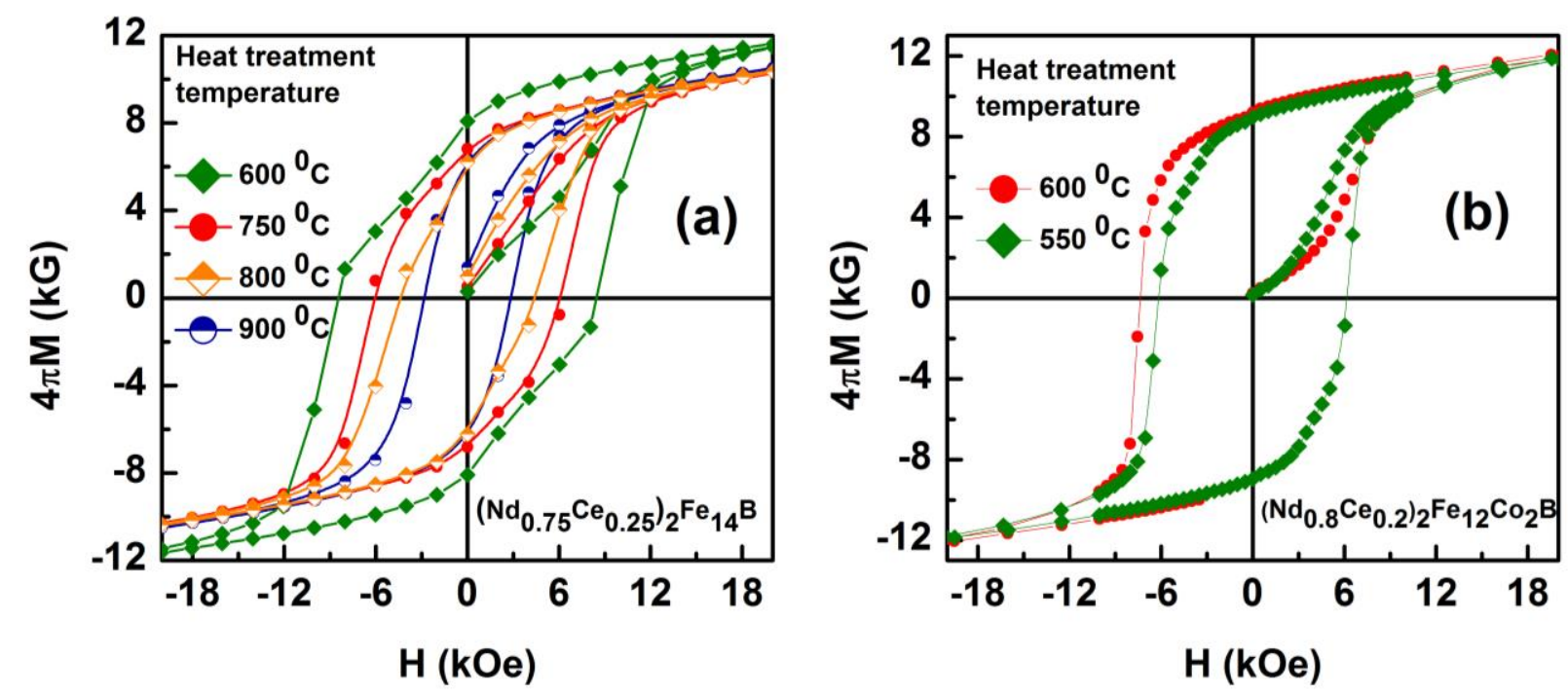

Fig. 3 (color online): Magnetization as function of magnetic field for melt spun ribbons

(a) $\left(\mathrm{Nd}_{0.75} \mathrm{Ce}_{0.25}\right)_{2} \mathrm{Fe}_{14} \mathrm{~B}$, and (b) $\left(\mathrm{Nd}_{0.8} \mathrm{Ce}_{0.2}\right)_{2} \mathrm{Fe}_{12} \mathrm{Co}_{2} \mathrm{~B}$ heat treated at different temperatures. 

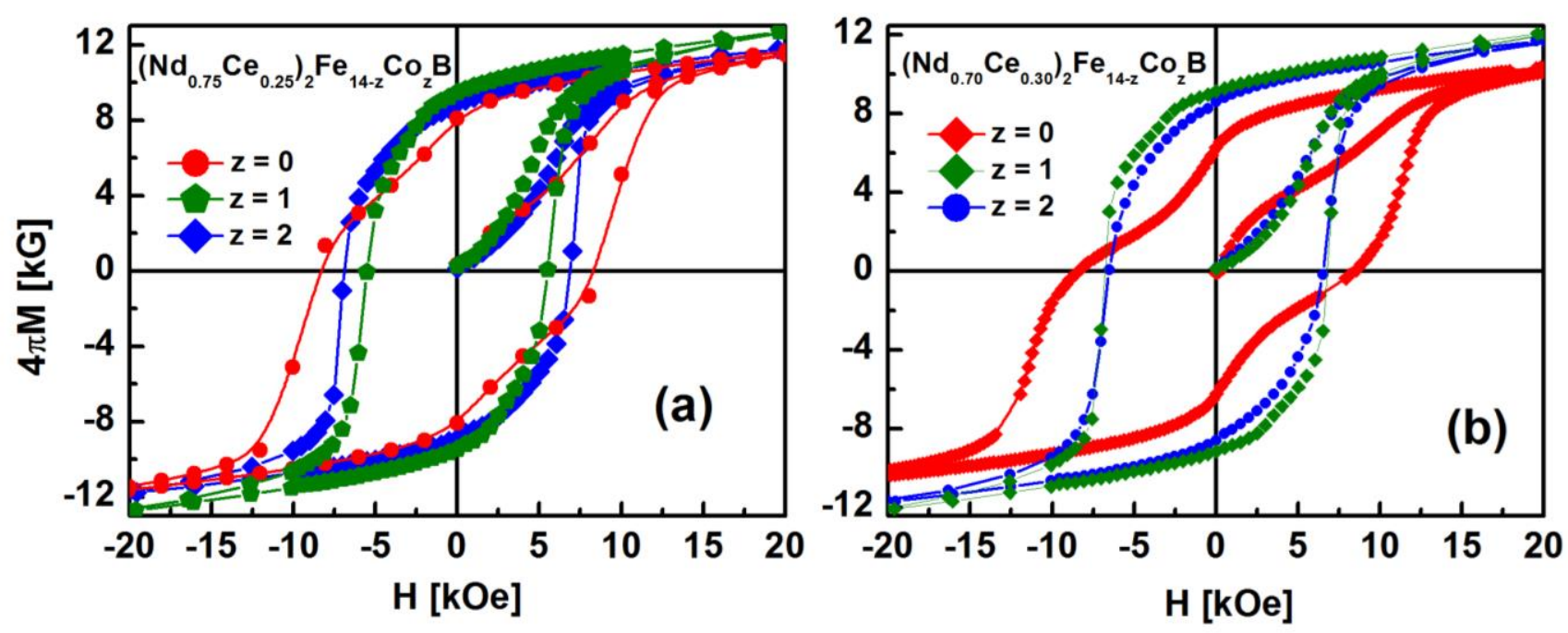

Fig. 3

Fig. 4 (color online): Magnetization versus magnetic field for melt spun ribbons (a) $\left(\mathrm{Nd}_{0.75} \mathrm{Ce}_{0.25}\right)_{2} \mathrm{Fe}_{14-\mathrm{z}} \mathrm{Co}_{\mathrm{z}} \mathrm{B}$ and (b) $\left(\mathrm{Nd}_{0.7} \mathrm{Ce}_{0.3}\right)_{2} \mathrm{Fe}_{14-\mathrm{z}} \mathrm{Co}_{\mathrm{z}} \mathrm{B}$. 

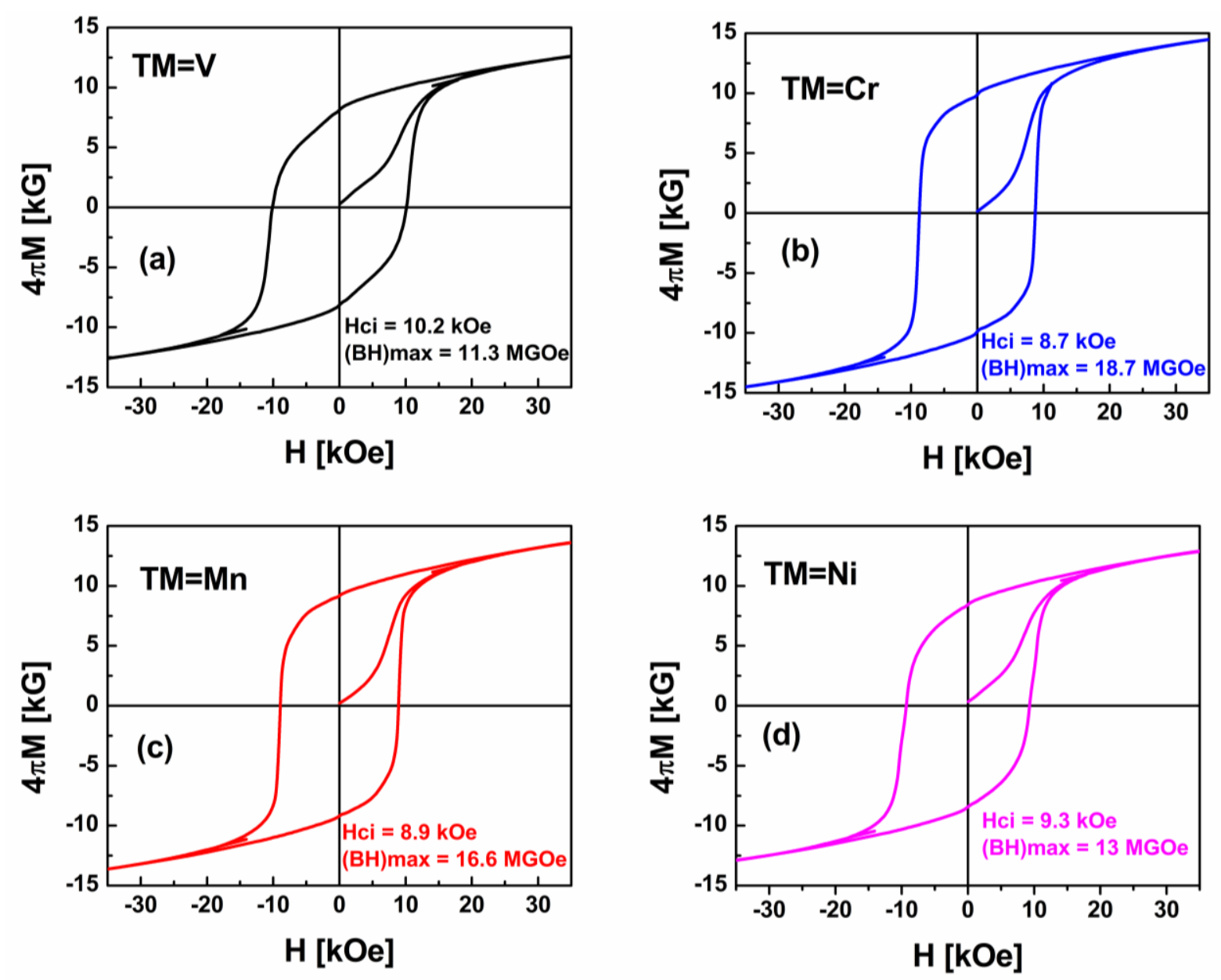

Fig. 5

Fig. 5 (color online): Room temperature magnetization versus magnetic field for melt spun ribbons $\left(\mathrm{Nd}_{0.8} \mathrm{Ce}_{0.2}\right)_{2} \mathrm{Fe}_{12}\left(\mathrm{Co}_{1.9} \mathrm{TM}_{0.1}\right) \mathrm{B}+2.5 \% \mathrm{ZrC}, \mathrm{TM}=$ (a) $\mathrm{V}$, (b) $\mathrm{Cr}$, (c) $\mathrm{Mn}$, and (d) Ni. 

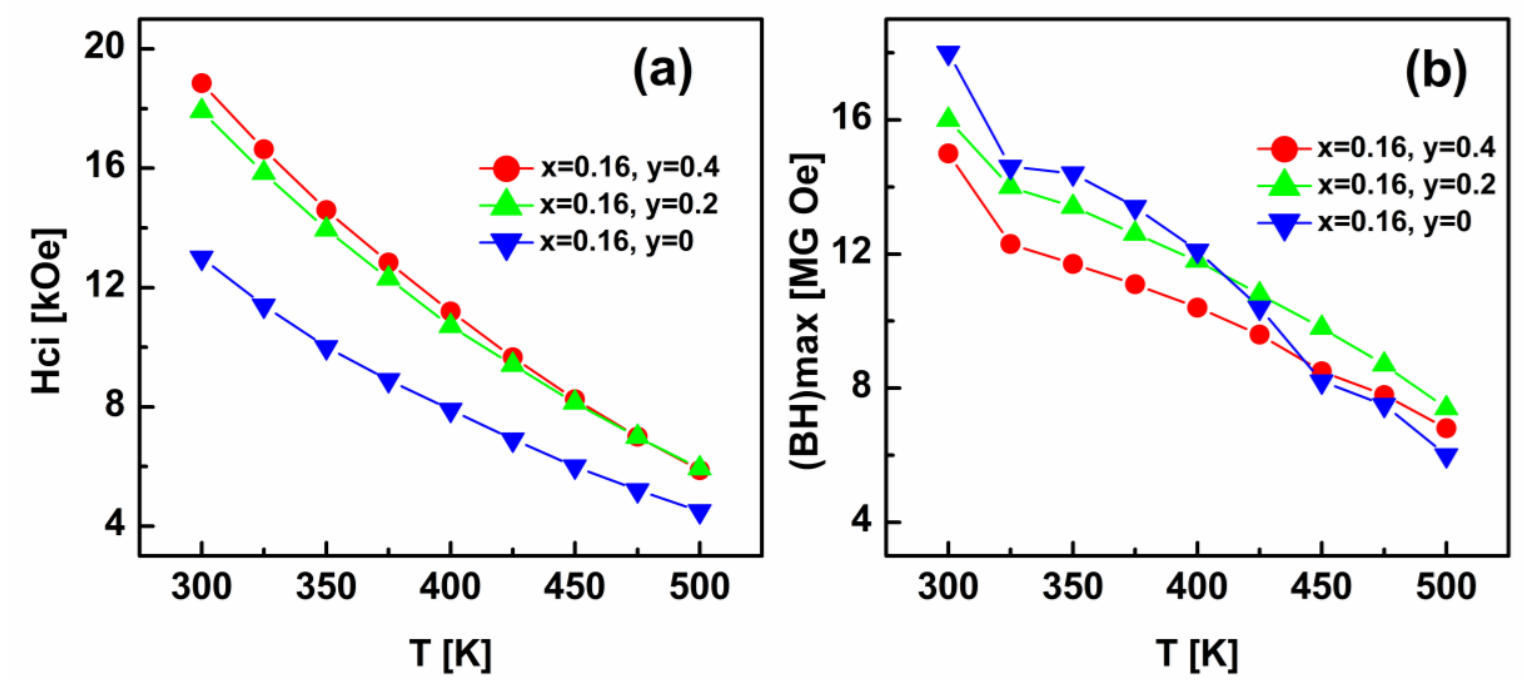

Fig. 6

Fig. 6 (color online): (a) Intrinsic coercivity, Hci vs. temperature, and (b) maximum energy product, $(\mathrm{BH}) \max v s$. temperature for melt spun ribbons $\left(\mathrm{Nd}_{0.8+\mathrm{x}} \mathrm{Ce}_{0.2}\right)_{2+\mathrm{y}} \mathrm{Fe}_{12} \mathrm{Co}_{2} \mathrm{~B}+2.5 \% \mathrm{ZrC}$. 
Table 1: Phase contents of drop cast $\left(\mathrm{Nd}_{1-\mathrm{x}} \mathrm{Ce}_{\mathrm{x}}\right)_{2} \mathrm{Fe}_{14} \mathrm{~B}$ alloys in as-cast (straight font) and heat treated (bold italic) state in wt.\%.

\begin{tabular}{|l|l|l|l|l|}
\hline $\begin{array}{l}\mathrm{Ce} \\
\mathrm{x}\end{array}$ & $\begin{array}{l}\mathrm{RE} 2 \mathrm{Fe} 14 \mathrm{~B} \\
(\%)\end{array}$ & $\begin{array}{l}\mathrm{RE} 2 \mathrm{Fe} 17 \\
\text { \% }\end{array}$ & $\begin{array}{l}\alpha-\mathrm{Fe} \\
\%\end{array}$ & $\begin{array}{l}\mathrm{CeFe} 2 \\
\%\end{array}$ \\
\hline 0 & 81.77 & 3.66 & 14.57 & 0 \\
& $\mathbf{9 8 . 5 9}$ & $\boldsymbol{0}$ & $\mathbf{1 . 4 1}$ & 0 \\
\hline 0.05 & 80.06 & 3.66 & 16.28 & 0 \\
& $\mathbf{9 8 . 4 4}$ & $\boldsymbol{0}$ & $\mathbf{1 . 5 6}$ & $\boldsymbol{0}$ \\
\hline 0.1 & 73.65 & 5.88 & 20.47 & 0 \\
& $\mathbf{9 9 . 0 5}$ & $\boldsymbol{0}$ & $\mathbf{0 . 9 5}$ & $\boldsymbol{0}$ \\
\hline 0.15 & 78.31 & 3.98 & 17.71 & 0 \\
& $\mathbf{9 9 . 1 9}$ & $\boldsymbol{0}$ & $\mathbf{0 . 8 1}$ & $\boldsymbol{0}$ \\
\hline 0.2 & 83.05 & 3.3 & 13.65 & 0 \\
& $\mathbf{9 9 . 5 4}$ & $\boldsymbol{0}$ & $\mathbf{0 . 4 6}$ & $\boldsymbol{0}$ \\
\hline 0.25 & 82.93 & 0 & 14.99 & 2.08 \\
& $\mathbf{9 9 . 0 6}$ & $\boldsymbol{0}$ & $\mathbf{0 . 9 4}$ & $\boldsymbol{0}$ \\
\hline 0.50 & 73.43 & 0 & 17.50 & 9.07 \\
& $\mathbf{9 8 . 9 2}$ & $\boldsymbol{0}$ & $\mathbf{1 . 5 9}$ & $\boldsymbol{0}$ \\
\hline 0.75 & 65.51 & 0 & 19.31 & 15.18 \\
& $\mathbf{9 8 . 9 2}$ & $\boldsymbol{0}$ & $\mathbf{1 . 0 8}$ & $\boldsymbol{0}$ \\
\hline 1 & 46.88 & 0 & 32.32 & 20.80 \\
& $\mathbf{9 8 . 4 9}$ & $\boldsymbol{0}$ & $\mathbf{1 . 5 1}$ & $\boldsymbol{0}$ \\
\hline
\end{tabular}


Table 2 (color online): Room temperature values of maximum energy product $(\mathrm{BH}) \mathrm{max}$, remanence magnetization $(\mathrm{Br})$, intrinsic coercivity Hci, Curie temperature $\mathrm{T}_{\mathrm{C}}$ of $\left(\mathrm{Nd}_{1-\mathrm{x}} \mathrm{Ce}_{\mathrm{x}}\right)_{2} \mathrm{Fe}_{14-\mathrm{z}} \mathrm{Co}_{\mathrm{z}} \mathrm{B}$ melt spun ribbons heat treated for 20 minutes at $600{ }^{\circ} \mathrm{C}$. The yellow highlighted (listed as bold italic values) rows represent the concentrations with (BH)max > 11 MGOe.

$\left(\mathrm{Nd}_{0.8} \mathrm{Ce}_{0.2}\right)_{2} \mathrm{Fe}_{14-\mathrm{z}} \mathrm{Co}_{\mathrm{z}} \mathrm{B}, \mathrm{x}=0.2$

\begin{tabular}{|l|l|l|l|l|}
\hline $\mathrm{z}$ & $\begin{array}{l}\text { (BH)max } \\
(\mathrm{MGOe})\end{array}$ & $\begin{array}{l}\mathrm{Br} \\
(\mathrm{kG})\end{array}$ & $\begin{array}{l}\text { Hci } \\
(\mathrm{kOe})\end{array}$ & $\begin{array}{l}\mathrm{T}_{\mathrm{C}} \\
(\mathrm{K})\end{array}$ \\
\hline 0 & 10.6 & 8.6 & 10 & 546 \\
\hline 1 & 11.2 & 8.6 & 6.4 & 620 \\
\hline 1.5 & 10.5 & 9 & 5.6 & 662 \\
\hline $\mathbf{1 . 7 5}$ & $\mathbf{1 3 . 2}$ & $\mathbf{8 . 9}$ & $\mathbf{7 . 5}$ & $\mathbf{6 7 0}$ \\
\hline $\mathbf{2}$ & $\mathbf{1 6}$ & $\mathbf{9}$ & $\mathbf{7 . 8}$ & $\mathbf{6 9 5}$ \\
\hline $\mathbf{2 . 2 5}$ & $\mathbf{1 4 . 3}$ & $\mathbf{9 . 2}$ & $\mathbf{6 . 8}$ & $\mathbf{7 0 7}$ \\
\hline $\mathbf{2 . 5}$ & $\mathbf{1 3 . 5}$ & $\mathbf{8 . 9}$ & $\mathbf{6 . 2}$ & $\mathbf{7 2 0}$ \\
\hline
\end{tabular}

$\left(\mathrm{Nd}_{0.75} \mathrm{Ce}_{0.25}\right)_{2} \mathrm{Fe}_{14-\mathrm{z}} \mathrm{Co}_{\mathrm{z}} \mathrm{B}, \mathrm{x}=0.25$

\begin{tabular}{|l|l|l|l|l|}
0 & 8.4 & 8.1 & 9 & 540 \\
\hline $\mathbf{1}$ & $\mathbf{1 3}$ & $\mathbf{9 . 5}$ & $\mathbf{5 . 5}$ & $\mathbf{6 1 5}$ \\
\hline $\mathbf{2}$ & $\mathbf{1 3}$ & $\mathbf{8 . 9}$ & $\mathbf{6 . 9}$ & $\mathbf{6 8 2}$ \\
\hline
\end{tabular}

$\left(\mathrm{Nd}_{0.7} \mathrm{Ce}_{0.3}\right)_{2} \mathrm{Fe}_{14-\mathrm{z}} \mathrm{Co}_{\mathrm{z}} \mathrm{B}, \mathrm{x}=0.3$

\begin{tabular}{|l|l|l|l|l|}
0 & 5.7 & 7.3 & 7.8 & 540 \\
\hline 1 & $\mathbf{1 4 . 4}$ & $\mathbf{9 . 2}$ & $\mathbf{6 . 8}$ & $\mathbf{6 0 8}$ \\
\hline 2 & $\mathbf{1 1 . 5}$ & $\mathbf{8 . 6}$ & $\mathbf{6 . 5}$ & $\mathbf{6 7 0}$ \\
\hline
\end{tabular}

$\left(\mathrm{Nd}_{0.65} \mathrm{Ce}_{0.35}\right)_{2} \mathrm{Fe}_{14-\mathrm{z}} \mathrm{Co}_{\mathrm{z}} \mathrm{B}, \mathrm{x}=0.35$

\begin{tabular}{|l|l|l|l|l|}
0 & 10.7 & 8.8 & 6 & 535 \\
\hline $\mathbf{1}$ & $\mathbf{1 2}$ & $\mathbf{8 . 6}$ & $\mathbf{6}$ & $\mathbf{- -}$ \\
\hline $\mathbf{2}$ & $\mathbf{1 2 . 2}$ & $\mathbf{8 . 7}$ & $\mathbf{6 . 4}$ & $\mathbf{6 7 0}$ \\
\hline
\end{tabular}

$\left(\mathrm{Nd}_{0.5} \mathrm{Ce}_{0.5}\right)_{2} \mathrm{Fe}_{14-\mathrm{z}} \mathrm{Co}_{\mathrm{z}} \mathrm{B}, \mathrm{x}=0.5$

\begin{tabular}{|l|l|l|l|l|}
0 & 9.5 & 7.9 & 4.9 & 520 \\
\hline 0.5 & 10.1 & 9.06 & 4.3 & 548 \\
\hline $\boldsymbol{1}$ & $\mathbf{1 4 . 6}$ & $\mathbf{8 . 2}$ & $\mathbf{8}$ & $\mathbf{5 9 0}$ \\
\hline $\mathbf{1 . 5}$ & $\mathbf{1 2}$ & $\mathbf{8 . 6}$ & $\mathbf{5 . 5}$ & $\mathbf{6 0 8}$ \\
\hline 2 & 7.6 & 7.8 & 4.8 & 636 \\
\hline 4 & 8.02 & 8.3 & 4.4 & 750 \\
\hline
\end{tabular}


Table 3: The room temperature magnetic properties: coercivity $\left(\mathrm{H}_{\mathrm{ci}}\right)$, maximum energy product $\left((\mathrm{BH})_{\max }\right)$, saturation magnetization $(\mathrm{Ms})$, and anisotropy field (Ha) of $\left(\mathrm{Nd}_{0.8} \mathrm{Ce}_{0.2}\right)_{2} \mathrm{Fe}_{12}\left(\mathrm{Co}_{1.9} \mathrm{TM}_{0.1}\right) \mathrm{B}+2.5 \% \mathrm{ZrC}, \mathrm{TM}=\mathrm{V}, \mathrm{Cr}, \mathrm{Mn}$, and Ni. For comparison, the corresponding values of the unsubstituted $\left(\mathrm{Nd}_{0.8} \mathrm{Ce}_{0.2}\right)_{2} \mathrm{Fe}_{12} \mathrm{Co}_{2} \mathrm{~B}+2.5 \% \mathrm{ZrC}$ sample are also provided in the bottom row.

\begin{tabular}{|c|c|c|c|c|}
\hline Samples & $\begin{array}{l}\text { Hci } \\
\text { kOe }\end{array}$ & $\begin{array}{l}(\mathrm{BH}) \max \\
\text { MGOe }\end{array}$ & $\begin{array}{l}\text { Ms } \\
\mathrm{kG}\end{array}$ & $\begin{array}{l}\mathrm{Ha} \\
\mathrm{kOe}\end{array}$ \\
\hline$\left(\mathrm{Nd}_{0.8} \mathrm{Ce}_{0.2}\right)_{2} \mathrm{Fe}_{12} \mathrm{Co}_{1.9} \mathrm{~V}_{0.1} \mathrm{~B}+2.5 \% \mathrm{ZrC}$ & 10.2 & 11.3 & 14.9 & 65 \\
\hline$\left(\mathrm{Nd}_{0.8} \mathrm{Ce}_{0.2}\right)_{2} \mathrm{Fe}_{12} \mathrm{Co}_{1.9} \mathrm{Cr}_{0.1} \mathrm{~B}+2.5 \% \mathrm{ZrC}$ & 8.7 & 18.7 & 16.9 & 68.3 \\
\hline$\left(\mathrm{Nd}_{0.8} \mathrm{Ce}_{0.2}\right)_{2} \mathrm{Fe}_{12} \mathrm{Co}_{1.9} \mathrm{Mn}_{0.1} \mathrm{~B}+2.5 \% \mathrm{ZrC}$ & 8.9 & 16.6 & 16.1 & 67.2 \\
\hline$\left(\mathrm{Nd}_{0.8} \mathrm{Ce}_{0.2}\right)_{2} \mathrm{Fe}_{12} \mathrm{Co}_{1.9} \mathrm{Ni}_{0.1} \mathrm{~B}+2.5 \% \mathrm{ZrC}$ & 9.3 & 13 & 15.3 & 66.1 \\
\hline$\left(\mathrm{Nd}_{0.8} \mathrm{Ce}_{0.2}\right)_{2.4} \mathrm{Fe}_{12} \mathrm{Co}_{1.9} \mathrm{Cr}_{0.1} \mathrm{~B}+2.5 \% \mathrm{ZrC}$ & 16.8 & 9.8 & 12.7 & 66.2 \\
\hline$\left(\mathrm{Nd}_{0.8} \mathrm{Ce}_{0.2}\right)_{2} \mathrm{Fe}_{12} \mathrm{Co}_{2} \mathrm{~B}+2.5 \% \mathrm{ZrC}$ & 10.2 & 16.2 & 16.4 & 68.3 \\
\hline
\end{tabular}




\section{References:}

${ }^{1}$ R. W. McCallum, L. H. Lewis, R. Skomski, M. J. Kramer, and I. E. Anderson, Annu. Rev. Mater. Res. 44, 451 (2014).

2 Critical Materials Strategy, U. S. Department of Energy, December 2011.

3 W. C. Chang, S. H. Wu, B. M. Ma, C. O. Bounds, J. Magn. Magn. Mat. 167, 65 (1997).

4 J. Röhler, Handbook on the Physics and Chemistry of Rare Earths, (Eds: K. A.

Gschneidner Jr., L. Eyring), Vol. 10, North-Holland Publishing Company, Amsterdam 1987, p. 453.

5 T. W. Capehart, R. K. Mishra, G. P. Meisner, C. D. Fuerst, J. F. Herbst, Appl. Phys. Lett. 63, 3642 (1993).

${ }^{6}$ M. Okada, S. Sugimoto, C. Ishizaka, T. Tanaka, and M. Homma, Appl. Phys. Phys. 57, 4146 (1985).

7 Z. Li, W. Liu, S. Zha, Y. Li, Y. Wang, D. Zhang, M. Yue, J. Zhang, and X. Huang, J. Magn. Magn Mat. 393, 551 (2015).

8 Z. Chen, Y. K. Lim, D. Brown, IEEE Trans. Magn. (DOI: 10.1109/TMAG.2015.2437376).

9 Z. B. Li, B. G. Shen, M. Zhang, F. X. Hu, J. R. Sun, J. Alloys and Comps. 628, 325 (2015).

10 D. Li, and Y. Bogatin, Appl. Phys. Phys. 69, 5515 (1991).

11 E. Niu, Z. A. Chen, G. A. Chen, Y. G. Zhao, J. Zhang, X. L. Rao, B. P. Hu, Z. X. Wang, J. Appl. Phys. 115, 113912 (2014).

12 S. Hirosawa, Y. Matsuura, H. Yamamoto, S. Fujimura, M. Sagawa and H. Yamauchi J. Appl. Phys 59, 873 (1986). 
13 A. K. Pathak, M. Khan, K. A. Gschneidner, Jr., R. W. McCallum, L. Zhou, K. Sun, K.W. Dennis, C. Zhou, F.E. Pinkerton, M. J. Kramer, and V. K. Pecharsky, Advanced Materials 27, 2663 (2015).

14 A. K. Pathak, M. Khan, K. A. Gschneidner, Jr., R. W. McCallum, L. Zhou, K. Sun, M. J. Kramer, and V. K. Pecharsky, Acta Mat. 103, 211 (2016).

15 B. Hunter, IUCR Comm. Powder Diff. Newsl. 20, 21 (1998).

16 Z. B. Li, M. Zhang, B. G. Shen, and J. R. Sun, Appl. Phys. Lett. 102, 102405 (2013)

17 A. Alam, and D. D. Johnson, Phys. Rev. B 89235126 (2014).

18 A. Alam, M. Khan, R. W. McCallum and D. D. Johnson, Appl. Phys. Lett 102, 042402 (2013).

19 E. J. Skoug, M. S. Meyer, F. E. Pinkerton, M. M. Tessema, D. Haddad, J. F. Herbst, J. Alloys Comp. 574, 552 (2013).

${ }^{20}$ D. H. Ryan, Z. Altounian, and J. O. Strom-Olsen, and W. B. Muir, Phys. Rev. B 39, 4730 (1989).

21 P. Deppe, M. Rosenberg, S. Hirosawa and M. Sagawa, J. Appl. Phys. 61, 4337 (1987).

22 J. F. Herbst and W. B. Yelon, J. Appl. Phys. 60, 4224 (1986).

23 L.X. Liao, Z. Altounian, and D. H. Ryan, Phys. Rev. B 47, 11230 (1993).

24 D. J. Branagan and R. W. McCallum, J. Magn. Magn. Mater. 14689 (1995).

25 K.A. Gschneidner, Jr., R.W. Mccallum, M. Khan, A.K. Pathak, V.K. Pecharsky, L.

Zhou, K. Sun, K.W. Dennis, M.J. Kramer, D. Brown, C. Zhou, Proceedings $23^{\text {rd }}$ International Workshop on Rare Earth and Future Permanent Magnets and Their Applications (REPM 2014), G.C. Hadjipanayis, C.H. Chen, J.P. Liu, editors, pp. 403406, Annapolis, Maryland, USA (August 17-21,2014). 
${ }^{26}$ C. Wang, M. Yan, and W. Y. Zhang, Mat. Sci. and Eng. B 123, 80 (2005).

27 K. Pei, X. Zhang, M. Lin, and A. Yan, J. Magn. Magn. Mater. 398, 96 (2016).

${ }^{28}$ Z. B. Li, B. G. Shen, M. Zhang, F. X. Hu, J. R. Sun, J. Alloys Compd. 618, 325 (2015). 